\title{
An efficient heterogeneous catalyst (CuO@ARF) for on-water C-S coupling reaction: an application to the synthesis of phenothiazine structural scaffold
}

Debasish Sengupta and Basudeb Basu*

\begin{abstract}
Background: Aryl sulfides have significant importance from biological and pharmaceutical aspects. Transition metal-catalyzed carbon-sulfur cross-coupling reaction represents an important tool for the synthesis of sulfides. Among various transition metals, copper salts or oxides have found vast applicability.
\end{abstract}

Results: A simple procedure for the preparation of poly-ionic amberlite resins embedded with copper oxide nanoparticles (CUO NPs) (denoted as CuO@ARF) has been developed, characterized, and employed for the first time as a heterogeneous ligand-free catalyst for 'on-water' C-S cross-coupling reaction. The NPs of CuO with an average size (approximately $2.6 \mathrm{~nm}$ ), as determined from high resolution transmission electron microscopy (HRTEM) images, are found to be a potentially active, chemoselective, and recyclable catalyst for the preparation of symmetrical and unsymmetrical aryl sulfides. Recycling of the catalyst was performed successfully for five consecutive runs, and apparently no leaching was observed in a hot filtration test. Excellent chemoselectivity between iodo- and bromo-arene has been exploited in step-wise C-S and C-N couplings to synthesize bioactive heterocyclic scaffold phenothiazine.

Conclusions: An efficient method is established for the C-S cross-coupling reaction using heterogeneous catalyst CuO@ARF under ligand-free on-water condition. The catalyst is highly chemoselective among different aryl halides, which has been demonstrated in the synthesis heterocyclic scaffold phenothiazine. Furthermore, it is recyclable for five consecutive runs examined.

Keywords: C-S cross-coupling; CuO NPs; Heterogeneous catalyst; On-water reaction; Phenothiazine

\section{Background}

The carbon-sulfur bonds are prevalent present in numerous medicinally important natural products [1-3]. Indeed, a number of drugs in various therapeutic uses such as HIV, cancer, diabetes, inflammatory, Alzheimer's, and Parkinson's diseases contain the aryl sulfide functional group [4-7]. A few biologically active compounds possessing a C-S bond are represented in Figure 1. For example, phenothiazines are an important class of organic compounds finding wide applications as drugs, insecticides, inhibitors of polymerization, antioxidants, paints, spectroscopic probes, etc. [8]. Therefore, in the recent era, the $\mathrm{sp}^{2} \mathrm{C}-\mathrm{S}$ bond formation has been the subject of intense

\footnotetext{
* Correspondence: basu_nbu@hotmail.com

Department of Chemistry, North Bengal University, Darjeeling 734013, India
}

study in organic synthesis and medicinal chemistry, and researchers develop diverse mild cross-coupling methodologies for these pharmaceuticals.

The conventional methods for the C-S bond formation involve reduction of aryl sulfones or aryl sulfoxides using strong reducing agents like DIBAL-H or $\mathrm{LiAlH}_{4}$ [9]. Besides, on-water $\mathrm{C}-\mathrm{S}$ bond formation has been reported via thiol addition to $\alpha, \beta$-unsaturated carbonyl compounds at room temperature [10]. In 1980, Migita et al. first showed the Pd-catalyzed thiation of aryl bromides using $\mathrm{Pd}\left(\mathrm{PPh}_{3}\right)_{4}$ [11]. Subsequently, other metals like nickel $[12,13]$, copper [12,14], cobalt [15], iron [16], rhodium [17], manganese [18], and indium [19] have also been employed, though in much less extent, as compared to other $\mathrm{C}-\mathrm{X}(\mathrm{X}=\mathrm{C}, \mathrm{O}$, $\mathrm{N}, \mathrm{P}$ ) coupling reactions. This is possibly due to the notion that sulfur might act as the poison to suppress 
<smiles>CC(=O)N1CCN(C(=O)/C=C/c2ccc(Sc3ccccc3C(C)C)c([N+](=O)[O-])c2)CC1</smiles>

LFA-1/ICAM-1 Antagonists

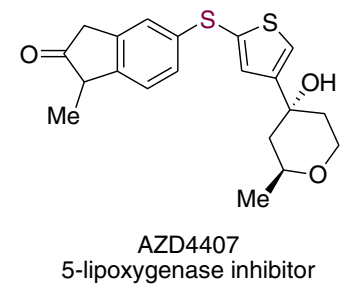

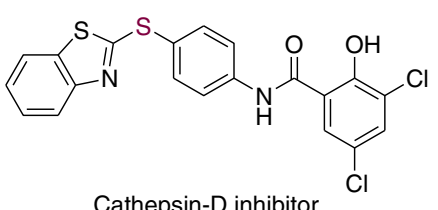

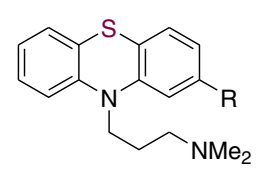

$\mathrm{R}=\mathrm{H}$, promazine

$\mathrm{R}=\mathrm{Cl}$, chlorpromazine

$\mathrm{R}=\mathrm{CF}_{3}$, triflupromazine

Used for Psychotropic medication

Figure 1 Some biologically active compounds bearing C-S bond.

the catalytic activity through strong coordinating and adsorptive properties [20]. However, the last two decades have witnessed several new transition metalbased catalytic systems for the C-S coupling reactions between aryl halides and thiols. Amongst various transition metals, copper has been considered as the most useful for the C-S coupling reactions due to its special redox properties and cost-effectiveness. Many strategies have been successful by using homogeneous copper salts in the presence of suitable electron-rich and precious ligands for the C-S coupling reactions [21,22].

On the other hand, nano-structured materials with high surface areas have been investigated as effective catalysts for various organic coupling reactions [23]. Catalysis of organic reactions by metal NPs supported on a suitable polymeric matrix offers the advantages of high catalytic activity, simplified isolation of the product, easy recovery, and recycling of the catalyst. Copper oxide nanoparticles ( $\mathrm{CuO} \mathrm{NPs}$ ) are a good choice and indeed useful catalyst in the C-S coupling reaction between aryl halide and thiols [24-26]. However, previous on-water C-S coupling reactions involving copper species like CuITBAB [27], $\mathrm{CuCl}$ [28], or other metal species like $\mathrm{Bi}_{2} \mathrm{O}_{3}$ [29], $\mathrm{CoCl}_{2} 6 \mathrm{H}_{2} \mathrm{O}$ [30], or $\mathrm{FeCl}_{3} 6 \mathrm{H}_{2} \mathrm{O}$-bipyridyl complexes [31], etc. afford thioethers without easy recovery of the catalyst and recyclability. Direct use of $\mathrm{CuO}$ either in bulk or NPs requires organic solvents other than water and gave relatively poor yields in C-S coupling reaction. Considering our experience in the field of developing polymer-supported metal NPs as the heterogeneous catalyst in various coupling reactions, [32,33] and in conjunction with our interest in the synthesis of various biologically important heterocyclic scaffolds mediated over solid supports, [34,35] we were interested to develop polymer-supported $\mathrm{CuO}$ NPs and to use it as the catalyst in 'on-water' C-S coupling reaction between aryl halide and thiols.
We report herein our studies that constitute simple preparation and characterization of poly-ionic amberlite resins embedded with $\mathrm{CuO}$ NPs (CuO@ARF), which efficiently catalyze the C-S cross-coupling reaction under on-water and ligand-free conditions. Further application of this catalyst has been demonstrated in the synthesis of phenothiazine - an important structural motif of several potentially useful drugs and also used as chemosensors [36].

\section{Methods}

Amberlite resin formate (ARF) was prepared from commercially available inexpensive amberlite resin chloride by an ion-exchange process as reported from this laboratory [37]. A mixture of ARF resin beads and $\mathrm{Cu}(\mathrm{OAc})_{2}$ $\mathrm{H}_{2} \mathrm{O}$ in DMF (50 $\mathrm{mg} \mathrm{g}^{-1}$ of ARF) was heated at $110^{\circ} \mathrm{C}$ in a Teflon-capped sealed tube for $30 \mathrm{~min}$ with occasional gentle shaking. White ARF beads turned brownish in color during the process. Finally, these resin beads were filtered off, washed with water and acetone, dried, and characterized by Fourier transform infrared spectroscopy (FT-IR), X-ray diffraction (XRD), and transmission electron microscopy (TEM) analysis, and the copper content of the composite was estimated by atomic absorption spectroscopy (AAS). The XRD and TEM analyses suggested the presence of $\mathrm{CuO}$ NPs distributed on the surface of ARF, and we referred the as-synthesized nanocomposite material as $\mathrm{CuO} @ \mathrm{ARF}$.

\section{Results and discussion}

At first, the presence of copper in the resin composite was measured by the AAS study. For this purpose, the sample $(100 \mathrm{mg})$ was digested with concentrated $\mathrm{HNO}_{3}$ $(1 \mathrm{~mL})$ and $\mathrm{Cu}$ content was estimated to be $0.145 \mathrm{mmol} \mathrm{g}^{-1}$ of the resin-copper nanocomposite. The FT-IR spectra of $\mathrm{CuO@ARF}$ were recorded and compared with those of ARF (Figure 2). In the case of a similar heterogeneous $\mathrm{Pd}$ or 


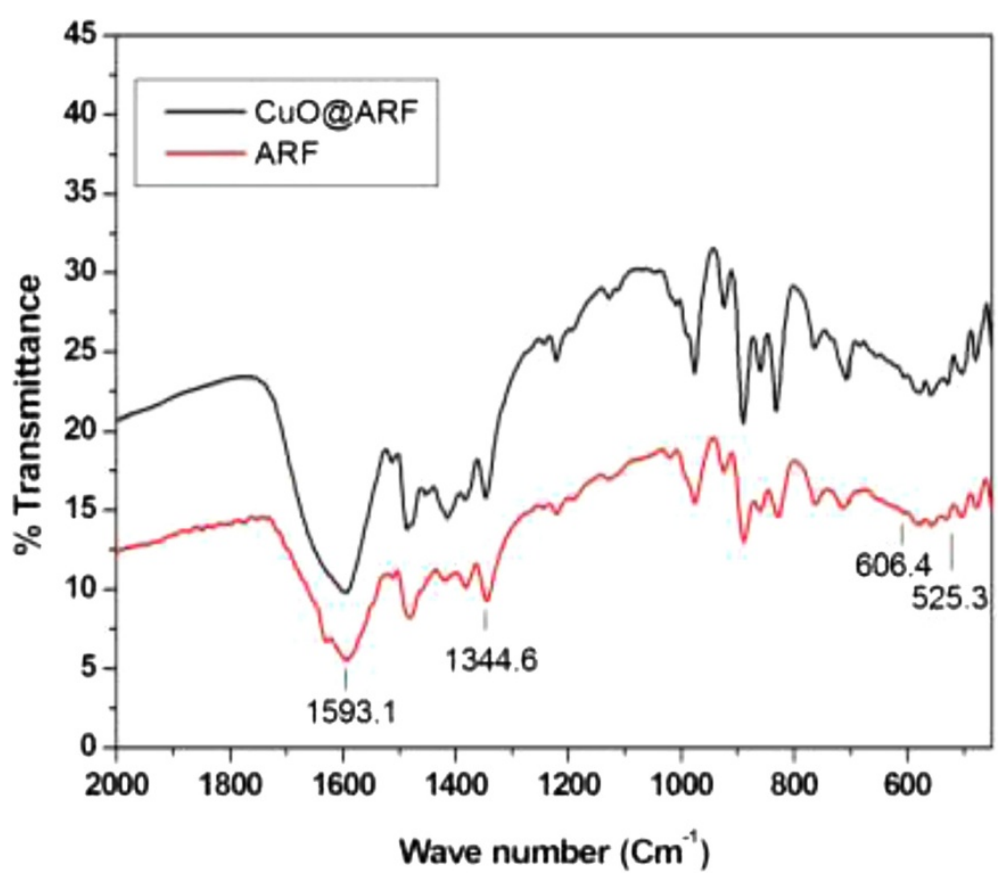

Figure 2 FT-IR spectra of the ARF and CuO@ARF.

bimetallic $\mathrm{Pd} / \mathrm{Cu}$ nanocomposites, as developed from this laboratory, a significant increase in the stretching frequency of the carboxylate anion $\left(\mathrm{HCOO}^{-}\right)$was observed [32,33]. Here, apparently no change of symmetric and anti-symmetric stretching vibrations (for the $\mathrm{HCOO}^{-}$) was observed and appeared respectively at about 1,345 and $1,593 \mathrm{~cm}^{-1}$ for both ARF and CuO@ARF species (Figure 2). However, the specific IR absorption bands of $\mathrm{CuO}$ at 606 and $525 \mathrm{~cm}^{-1}$ might overlap with those of ARF in the similar region [38].

We therefore examined the powder XRD patterns of ARF and those of $\mathrm{CuO} @ \mathrm{ARF}$, as shown in Figure 3. The ARF resins are amorphous in nature, and the Bragg diffraction patterns of $\mathrm{CuO@ARF}$ indicate the presence of cupric oxide $(\mathrm{CuO})$. The JCPDS peak positions of the CuO@ARF nanocomposite with relative intensities are in good agreement (Figure $3 \mathrm{~b}$ ). The presence of XRD peaks at $2 \theta$ of $35.39^{\circ}, 38.29^{\circ}, 38.99^{\circ}, 57.91^{\circ}$, and $61.64^{\circ}$ suggested the presence of $\mathrm{CuO}(\overline{1} 11),(111)$, (200), (202), and (113) planes, respectively (JCPDS\#01089-2531). Further examination of high resolution TEM (HRTEM) images of the CuO@ARF at different magnifications (Figure 4a,b) suggested that the CuO NPs are embedded on the resin polymeric matrices with an average size around $2.6 \mathrm{~nm}$ (Figure 4c).
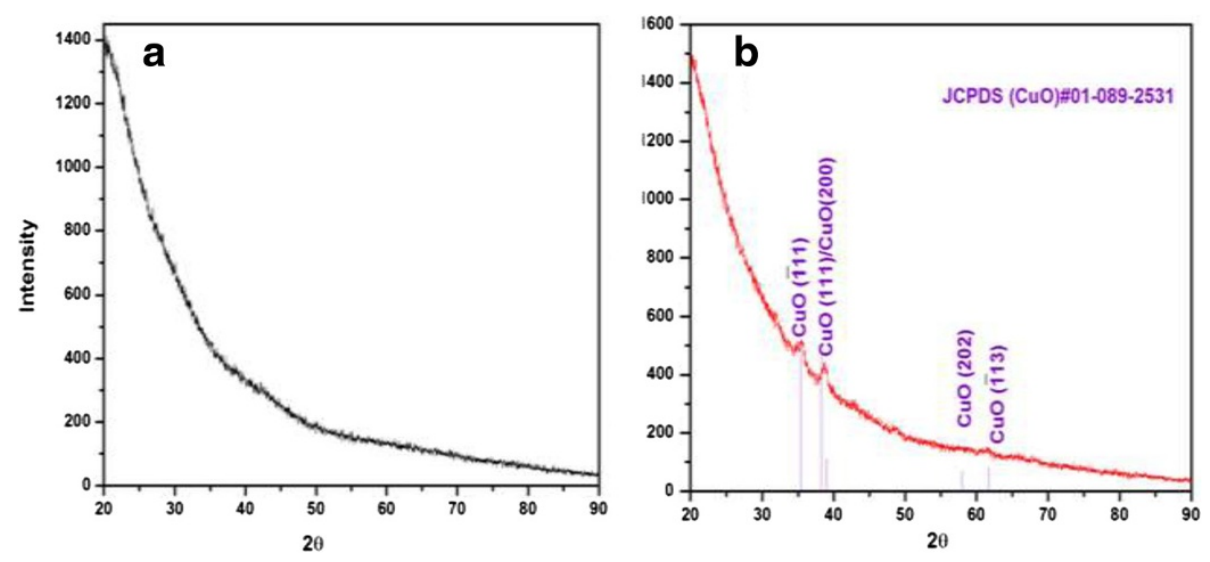

Figure 3 XRD patterns of (a) ARF and (b) CuO embedded on the surface of amberlite resin formate (CuO@ARF). 


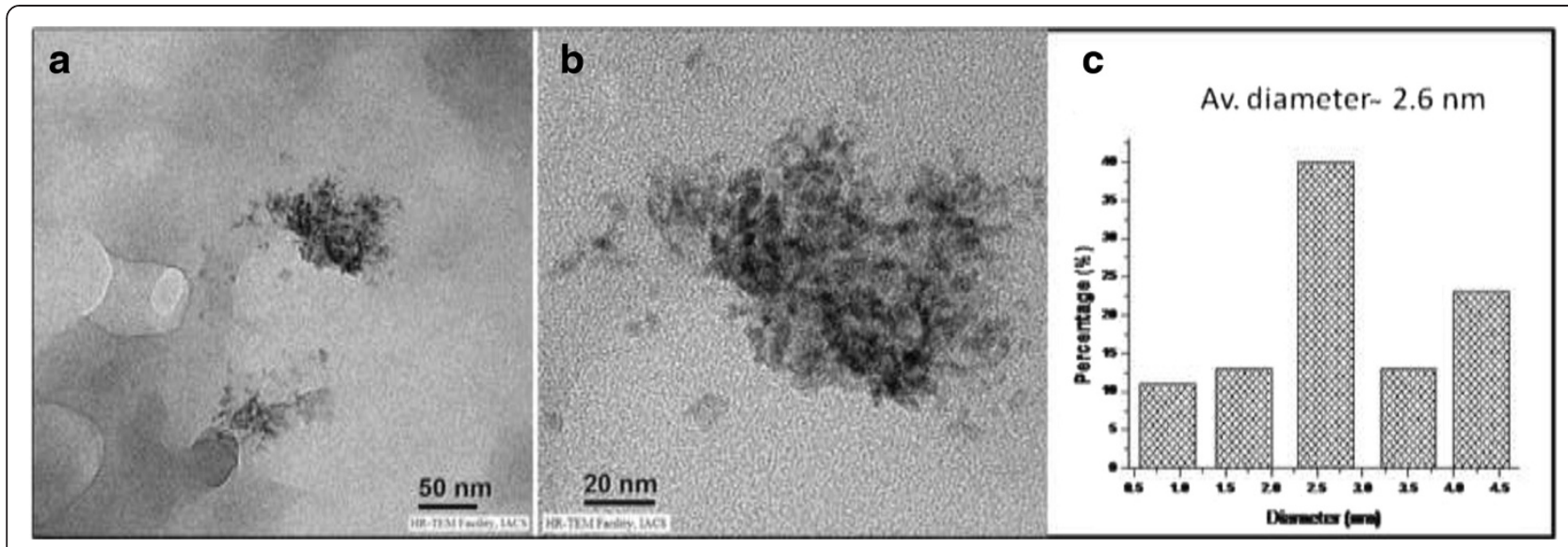

Figure 4 TEM images of CuO@ARF. (a) Scale bar 50 nm; (b) 20 nm; (c) average particle size from (b).

\section{Catalytic activity of CuO@ARF}

In order to evaluate the catalytic activity of this newly developed nanocomposite (CuO@ARF) in C-S cross-coupling reaction between aryl halide and thiol, we performed a model study by taking a mixture of 4-iodoanisole and benzenethiol (in 1:1.2 ratios) and the catalyst $\left(200 \mathrm{mg} \mathrm{mmol}^{-1}\right.$ of aryl iodide) in water (Table 1). The first reaction in the presence of a base $\left(\mathrm{K}_{2} \mathrm{CO}_{3}\right)$ at $100^{\circ} \mathrm{C}$ did afford the desired unsymmetrical sulfane but with a modest yield (62\%) (Table 1, entry 1). Considering that the modest conversion might be due to the poor solubility of aryl iodide in water, we used an additive - tetrabutylammonium bromide (TBAB), in equimolar quantity. This afforded the corresponding thioether in fairly good yield (83\%; entry 2 ). Further improvement was achieved by using the catalytic amount of sodium dodecyl sulfate (SDS; $10 \mathrm{~mol} \%$ ), [39] which furnished the desired product in $90 \%$ isolated yield (entry 3). While there was no cross-coupling observed at room temperature, reaction carried out at $60^{\circ} \mathrm{C}$ or in the absence of the base produced the sulfane in $56 \%$ to $68 \%$ isolated yields (entries 4 to 6 ). We also tried the reaction in $\mathrm{DMF}$ at $100^{\circ} \mathrm{C}$, which did not produce the desired

Table 1 Optimization of reaction condition for the C-S cross-coupling using CuO@ARF

\begin{tabular}{lllllc}
\hline Entry & Solvent & Base & Additive & Temperature/time & Yield (\%) $)^{\mathbf{b}, \mathbf{c}}$ \\
\hline 1 & Water & $\mathrm{K}_{2} \mathrm{CO}_{3}$ & - & $100^{\circ} \mathrm{C} / 24 \mathrm{~h}$ & 62 \\
$2^{\mathrm{d}}$ & Water & $\mathrm{K}_{2} \mathrm{CO}_{3}$ & $\mathrm{TBAB}$ & $100^{\circ} \mathrm{C} / 8 \mathrm{~h}$ & 83 \\
$3^{e}$ & Water & $\mathrm{K}_{2} \mathrm{CO}_{3}$ & $\mathrm{SDS}$ & $100^{\circ} \mathrm{C} / 8 \mathrm{~h}$ & 90 \\
$4^{\mathrm{e}}$ & Water & $\mathrm{K}_{2} \mathrm{CO}_{3}$ & $\mathrm{SDS}$ & $\mathrm{RT} / 24 \mathrm{~h}$ & 00 \\
$5^{\mathrm{e}}$ & Water & $\mathrm{K}_{2} \mathrm{CO}_{3}$ & $\mathrm{SDS}$ & $60^{\circ} \mathrm{C} / 24 \mathrm{~h}$ & 68 \\
$6^{\mathrm{e}}$ & Water & - & $\mathrm{SDS}$ & $100^{\circ} \mathrm{C} / 24 \mathrm{~h}$ & 56 \\
7 & DMF & $\mathrm{K}_{2} \mathrm{CO}_{3}$ & - & $100^{\circ} \mathrm{C} / 24 \mathrm{~h}$ & 67
\end{tabular}

a-lodoanisole (1 mmol), benzenethiol (1.2 mmol), CuO@ARF (200 mg), $\mathrm{K}_{2} \mathrm{CO}_{3}$ $(1.1 \mathrm{mmol})$, and solvent $(3 \mathrm{~mL}) .{ }^{\mathrm{b}}$ Isolated yield. ${ }^{\mathrm{C} S m a l l}$ quantity of diphenyl disulfide was formed ( $\leq 5 \%)$. ${ }^{d}$ TBAB (1 eqv) was used. ${ }^{\text {e }}$ SDS (10 mol\%) was used. sulfane in very good yield (entry 7). In each case, a small quantity of the diphenylsulfide $(\leq 5 \%)$ as the side product was also formed.

\section{Minimum loading of the catalyst}

After optimizing the reaction conditions, we examined the minimum amount of the catalyst loading that is required to obtain effective conversion to sulfane. Experiments were performed with 4-iodoanisole $(1 \mathrm{mmol})$ in the presence of varying quantities of $\mathrm{CuO} @ \mathrm{ARF}$ (from $50 \mathrm{mg}$ to $250 \mathrm{mg}$; i.e., $0.46 \mathrm{mg}$ to $2.30 \mathrm{mg}$ of copper mmol ${ }^{-1}$ of iodoarene) and the results are shown in Figure 5. Conversions to the thioether at different time intervals were measured by high-performance liquid chromatography (HPLC) and the plot of percent conversion $( \pm 2 \%)$ versus time (h) revealed that minimum $200 \mathrm{mg}$ of the catalyst (approximately $1.8 \mathrm{mg}$ of copper) $\mathrm{mmol}^{-1}$ of iodoarene can give rise to the best result. In each case, reaction was continued up to $24 \mathrm{~h}$ and HPLC analysis showed no appreciable changes in the conversion (Figure 5 was plotted up to $12 \mathrm{~h}$ ).

The optimized reaction conditions were then employed with different iodoarenes and other aromatic halides to couple with variety of aryl thiols to examine the scope and limitations of our catalyst for on-water C-S cross-coupling reaction. In general, it was observed that the crosscoupling reaction was successful producing corresponding diaryl sulfide in good to excellent yields. The results are presented in Table 2. Iodoarenes with both activated (methoxy, methyl) and deactivated functional groups (nitro or acetyl) effectively underwent C-S cross-coupling with different aryl thiols (entries 1 to 5). On the other hand, similar coupling reactions with bromo- and chlorobenzenes, including $p$-chloroacetophenone were not successful (entries 6 and 7). Increasing the catalyst loading and changing the base did not facilitate the C-S cross-coupling of $p$-bromotoluene (entry 8 ). The selectivity however might be useful for substrates bearing different halides. Thus, iodobromoarenes and 


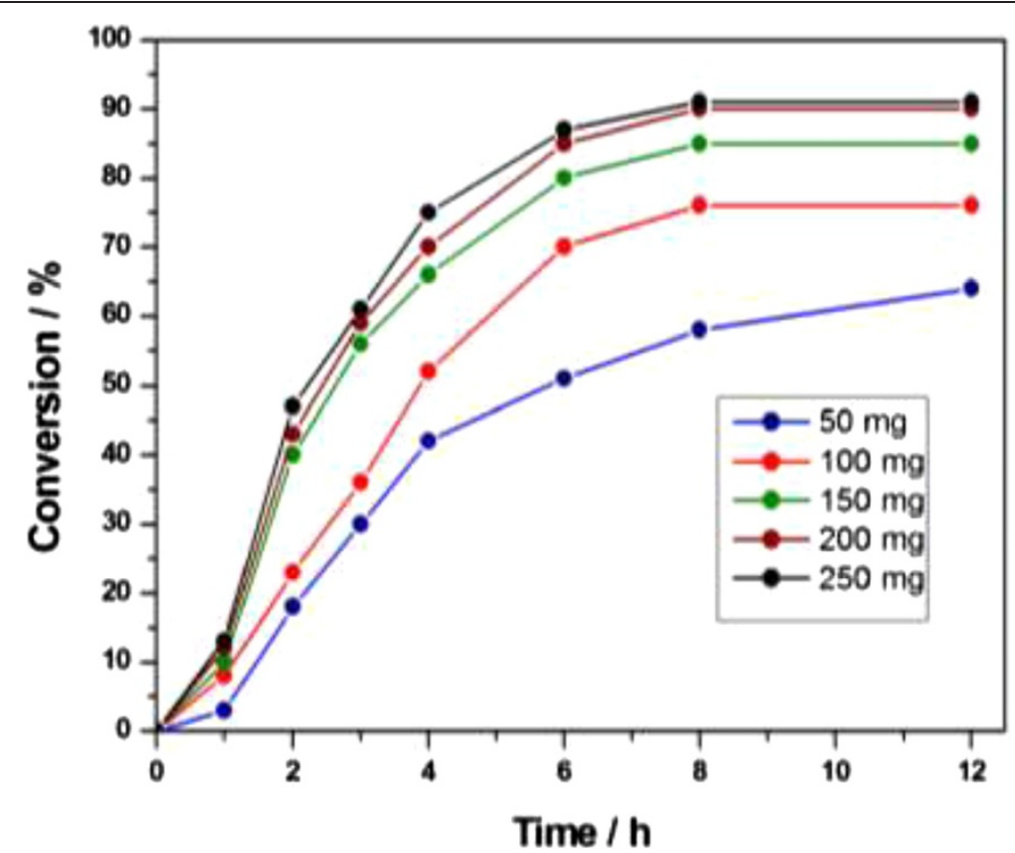

Figure 5 Time conversion plots for the C-S cross-coupling between 4-iodoanisole and thiophenol.

iodochloroarene were subjected to coupling with aryl thiols in the presence of this heterogeneous catalyst affording highly chemoselective iodo-coupled product only (entries 9 to 11). Substituted thiophenol like 2,5-dimethylbenzenethiol underwent smooth reactions giving the corresponding unsymmetrical diarylsulfide in $89 \%$ isolated yield (entry 12).
Aliphatic thiols also gave cross-coupling products without any difficulty but relatively in lower yields as compared to aromatic thiols (entries 13 to 15), which might be attributable to the fact that aliphatic thiols are less reactive than aromatic thiols [40]. Bis-couplings were performed equally efficiently starting from 1,3-diiodobenzene and $p$-tolylthiol

Table 2 CuO@ARF-catalyzed C-S cross-coupling reactions between haloarenes and thiol ${ }^{\mathrm{a}}$

\begin{tabular}{|c|c|c|c|c|c|}
\hline Entry & Aryl halide & Thiol & Time (h) & Product & Yield $(\%)^{b}$ \\
\hline 1 & $\left(4-\mathrm{H}_{3} \mathrm{CO}\right) \mathrm{C}_{6} \mathrm{H}_{4} \mathrm{I}$ & $\mathrm{C}_{6} \mathrm{H}_{5} \mathrm{SH}$ & 8 & $\left(4-\mathrm{H}_{3} \mathrm{CO}\right) \mathrm{H}_{4} \mathrm{C}_{6}-\mathrm{S}-\mathrm{C}_{6} \mathrm{H}_{5}$ & 90 \\
\hline 2 & $\left(3-\mathrm{H}_{3} \mathrm{CO}\right) \mathrm{C}_{6} \mathrm{H}_{4} \mathrm{l}$ & $(4-\mathrm{C} 1) \mathrm{C}_{6} \mathrm{H}_{4} \mathrm{SH}$ & 12 & $\left(3-\mathrm{H}_{3} \mathrm{CO}\right) \mathrm{H}_{4} \mathrm{C}_{6}-\mathrm{S}-\mathrm{C}_{6} \mathrm{H}_{4}(4-\mathrm{C} 1)$ & 85 \\
\hline 3 & $\left(2-\mathrm{H}_{3} \mathrm{CO}\right) \mathrm{C}_{6} \mathrm{H}_{4} \mathrm{l}$ & $\left(4-\mathrm{CH}_{3}\right) \mathrm{C}_{6} \mathrm{H}_{4} \mathrm{SH}$ & 18 & $\left(2-\mathrm{H}_{3} \mathrm{CO}\right) \mathrm{H}_{4} \mathrm{C}_{6}-\mathrm{S}-\mathrm{C}_{6} \mathrm{H}_{4}\left(4-\mathrm{CH}_{3}\right)$ & 75 \\
\hline 4 & $\left(3-\mathrm{NO}_{2}\right) \mathrm{C}_{6} \mathrm{H}_{4} \mathrm{I}$ & $\left(4-\mathrm{CH}_{3}\right) \mathrm{C}_{6} \mathrm{H}_{4} \mathrm{SH}$ & 11 & $\left(3-\mathrm{NO}_{2}\right) \mathrm{H}_{4} \mathrm{C}_{6}-\mathrm{S}-\mathrm{C}_{6} \mathrm{H}_{4}\left(4-\mathrm{CH}_{3}\right)$ & 78 \\
\hline 5 & $\left(4-\mathrm{H}_{3} \mathrm{CO}\right) \mathrm{C}_{6} \mathrm{H}_{4} \mathrm{l}$ & $\left(4-\mathrm{CH}_{3}\right) \mathrm{C}_{6} \mathrm{H}_{4} \mathrm{SH}$ & 10 & $\left(4-\mathrm{H}_{3} \mathrm{CO}\right) \mathrm{H}_{4} \mathrm{C}_{6}-\mathrm{S}-\mathrm{C}_{6} \mathrm{H}_{4}\left(4^{\prime}-\mathrm{CH}_{3}\right)$ & 75 \\
\hline 6 & $\left(4-\mathrm{H}_{3} \mathrm{C}\right) \mathrm{C}_{6} \mathrm{H}_{4} \mathrm{Br}$ & $\mathrm{C}_{6} \mathrm{H}_{5} \mathrm{SH}$ & 24 & No reaction & - \\
\hline 7 & $\left(4-\mathrm{CH}_{3} \mathrm{CO}\right) \mathrm{C}_{6} \mathrm{H}_{4} \mathrm{Cl}$ & $\mathrm{C}_{6} \mathrm{H}_{5} \mathrm{SH}$ & 24 & No reaction & - \\
\hline $8^{c}$ & $\left(4-\mathrm{H}_{3} \mathrm{C}\right) \mathrm{C}_{6} \mathrm{H}_{4} \mathrm{Br}$ & $\mathrm{C}_{6} \mathrm{H}_{5} \mathrm{SH}$ & 24 & No reaction & - \\
\hline 9 & $(5-\mathrm{Br})\left(2-\mathrm{H}_{3} \mathrm{CO}\right) \mathrm{C}_{6} \mathrm{H}_{3} \mathrm{I}$ & $\mathrm{C}_{6} \mathrm{H}_{5} \mathrm{SH}$ & 8 & $(5-\mathrm{Br})\left(2-\mathrm{H}_{3} \mathrm{CO}\right) \mathrm{H}_{3} \mathrm{C}_{6}-\mathrm{S}-\mathrm{C}_{6} \mathrm{H}_{5}$ & 90 \\
\hline 10 & $(3-\mathrm{Br}) \mathrm{C}_{6} \mathrm{H}_{4} \mathrm{l}$ & $\left(4-\mathrm{CH}_{3}\right) \mathrm{C}_{6} \mathrm{H}_{4} \mathrm{SH}$ & 16 & $(3-\mathrm{Br}) \mathrm{H}_{4} \mathrm{C}_{6}-\mathrm{S}-\mathrm{C}_{6} \mathrm{H}_{4}\left(4-\mathrm{CH}_{3}\right)$ & 79 \\
\hline 11 & $(3-\mathrm{C} 1) \mathrm{C}_{6} \mathrm{H}_{4} \mathrm{I}$ & $\left(4-\mathrm{CH}_{3}\right) \mathrm{C}_{6} \mathrm{H}_{4} \mathrm{SH}$ & 16 & $(3-\mathrm{C} 1) \mathrm{H}_{4} \mathrm{C}_{6}-\mathrm{S}-\mathrm{C}_{6} \mathrm{H}_{4}\left(4-\mathrm{CH}_{3}\right)$ & 79 \\
\hline 12 & $\left(4-\mathrm{H}_{3} \mathrm{CO}\right) \mathrm{C}_{6} \mathrm{H}_{4} \mathrm{I}$ & $\left(2,5-\left(\mathrm{CH}_{3}\right)_{2}\right) \mathrm{C}_{6} \mathrm{H}_{4} \mathrm{SH}$ & 7 & $\left(4-\mathrm{H}_{3} \mathrm{CO}\right) \mathrm{H}_{4} \mathrm{C}_{6}-\mathrm{S}-\mathrm{C}_{6} \mathrm{H}_{3}\left(2,5-\left(\mathrm{CH}_{3}\right)_{2}\right)$ & 89 \\
\hline 13 & $\left(4-\mathrm{H}_{3} \mathrm{CO}\right) \mathrm{C}_{6} \mathrm{H}_{4} \mathrm{l}$ & CySH & 16 & $\left(4-\mathrm{H}_{3} \mathrm{CO}\right) \mathrm{H}_{4} \mathrm{C}_{6}-\mathrm{S}-\mathrm{Cy}$ & 70 \\
\hline 14 & $\left(4-\mathrm{H}_{3} \mathrm{CO}\right) \mathrm{C}_{6} \mathrm{H}_{4} \mathrm{l}$ & $n-\mathrm{C}_{5} \mathrm{H}_{11} \mathrm{SH}$ & 16 & $\left(4-\mathrm{H}_{3} \mathrm{CO}\right) \mathrm{H}_{4} \mathrm{C}_{6}-\mathrm{S}-\mathrm{C}_{5} \mathrm{H}_{11}-n$ & 73 \\
\hline 15 & $\left(3-\mathrm{H}_{3} \mathrm{CO}\right) \mathrm{C}_{6} \mathrm{H}_{4} \mathrm{l}$ & $n-\mathrm{C}_{7} \mathrm{H}_{11} \mathrm{SH}$ & 16 & $\left(4-\mathrm{H}_{3} \mathrm{CO}\right) \mathrm{H}_{4} \mathrm{C}_{6}-\mathrm{S}-\mathrm{C}_{7} \mathrm{H}_{15}-n$ & 76 \\
\hline $16^{d}$ & $1,3-\mathrm{C}_{6} \mathrm{H}_{4} \mathrm{I}_{2}$ & $\left(4-\mathrm{CH}_{3}\right) \mathrm{C}_{6} \mathrm{H}_{4} \mathrm{SH}$ & 14 & $1,3-\left(\left(4-\mathrm{CH}_{3}\right) \mathrm{C}_{6} \mathrm{H}_{4} \mathrm{~S}\right)_{2}-\mathrm{C}_{6} \mathrm{H}_{4}$ & 79 \\
\hline 17 & $(2-\mathrm{Br}) \mathrm{C}_{6} \mathrm{H}_{4} \mathrm{l}$ & $\left(2-\mathrm{NH}_{2}\right) \mathrm{C}_{6} \mathrm{H}_{4} \mathrm{SH}$ & 8 & $(2-\mathrm{Br}) \mathrm{H}_{4} \mathrm{C}_{6}-\mathrm{S}-\mathrm{C}_{6} \mathrm{H}_{4}\left(2-\mathrm{NH}_{2}\right)$ & 82 \\
\hline
\end{tabular}

${ }^{a}$ Aryl halide: thiol: catalyst ( $\left.1 \mathrm{mmol}: 1.2 \mathrm{mmol}: 200 \mathrm{mg}\right)$, SDS $(10 \mathrm{~mol} \%)$, and $\mathrm{K}_{2} \mathrm{CO}_{3}(1.1 \mathrm{mmol})$ were taken in water $(3 \mathrm{~mL})$ and heated at $100^{\circ} \mathrm{C}$. ${ }^{\mathrm{b}} \mathrm{Yield}$ refers to pure isolated products characterized by spectroscopic ( ${ }^{1} \mathrm{H}$ and $\left.{ }^{13} \mathrm{C} \mathrm{NMR}\right)$ data. ${ }^{\mathrm{c}} \mathrm{Catalyst}\left(300 \mathrm{mg} \mathrm{mmol}^{-1}\right.$ of aryl bromide), SDS (10 mol\%), and $\mathrm{Cs}_{2} \mathrm{CO} \mathrm{O}_{3}(1.1 \mathrm{mmol})$. ${ }^{\mathrm{d}}$ Aryl halide: thiol: catalyst $(0.5 \mathrm{mmol}: 1.2 \mathrm{mmol}: 200 \mathrm{mg})$, SDS $(10 \mathrm{~mol} \%)$, and $\mathrm{K}_{2} \mathrm{CO}_{3}(1.1 \mathrm{mmol})$ were taken in water $(3 \mathrm{~mL})$. 
and affording the desired 1,3-bis( $p$-tolylthio)benzene as the only product in $79 \%$ isolated yield (entry 16). It may be mentioned that only benzenethiol and 4-tolylthiol gave a minor quantity of corresponding disulfides during the reaction $(\leq 5 \%)$, while in other cases, no disulfide was detected on thin-layer chromatography (TLC) or by HPLC analysis.

As reported previously [26], the mechanism of the resin embedded $\mathrm{CuO}$-catalyzed $\mathrm{C}$-S coupling reaction is believed to proceed through the oxidative addition followed by reaction with thiol and then reductive elimination steps $\left(\mathrm{Cu}^{\mathrm{II}} \rightarrow \mathrm{Cu}^{\mathrm{III}} \rightarrow \mathrm{Cu}^{\mathrm{II}}\right)$. The role of the additive SDS is presumably to solubilize the organic substrates in an aqueous medium [41,42]. Further beneficial assistance of the 'microreactors' formed by the surfactant like SDS in water medium organic reactions, as observed in other cases, cannot be ruled out [43]. In addition, the role of water might be attributed to the H-bonding (HB) effect, as reported previously on other occasions [44], has also been noticed in our cases. Thus, we isolated the crosscoupled product in higher yield performing the reaction in an aqueous medium as compared to in DMF (Table 1 , entries 3 and 7).

Leaching of any metallic species from the amberlite resin polymeric matrices during or after the reaction was tested following the literature procedure $[33,45]$. Accordingly, the reaction mixture of the $\mathrm{C}-\mathrm{S}$ cross-coupling between 4-iodoanisole and thiophenol is filtered off to separate out the solid catalysts after $2 \mathrm{~h}$ in hot condition, and the filtrate was analyzed by HPLC (approximately
43\% conversion). The AAS analysis of the filtrate solution did not show the presence of any copper species. Moreover, further continuing the reaction by heating the liquid phase at $100^{\circ} \mathrm{C}$ for another $6 \mathrm{~h}$ in the absence of any added catalyst (CuO@ARF) did not afford any appreciable conversion (HPLC analysis). These observations signify that any copper species might not be leached out from the heterogeneous support during the initial $2 \mathrm{~h}$ of the reaction (Figure 6).

One of the important factors for a heterogeneous catalyst lies in its efficiency for recycling. We investigated the reusability of $\mathrm{CuO@ARF}$ in the reaction between 4-iodoanisole and thiophenol again as the model case. After completion of the reaction, resin beads were filtered off from the reaction mixture, washed thoroughly with water followed by acetone (two times), and then dried under vacuum. The catalyst was reused in five consecutive runs including the first run. Gratifyingly, there was no considerable loss of the catalytic efficiency observed (Figure 7).

Since the present catalytic system is highly selective to aryl iodides only (i.e., the first oxidative addition to the $\mathrm{sp}^{2} \mathrm{C}$-I bond), we decided to utilize this chemoselectivity between iodo- and bromo-substituents attached to the aryl moiety. Thus, a reaction of 1,2-bromoiodobenzene with 2-aminothiophenol in the presence of the catalyst $\mathrm{CuO@ARF} \mathrm{under} \mathrm{similar} \mathrm{conditions} \mathrm{in} \mathrm{water} \mathrm{was} \mathrm{per-}$ formed. The C-S coupling occurred selectively at the $\mathrm{sp}^{2} \mathrm{C}$-I bond, and we obtained 2-(2-bromophenylthio) benzene in $82 \%$ yield (Scheme 1). Further intramolecular Buchwald-Hartwig type coupling between amino-and

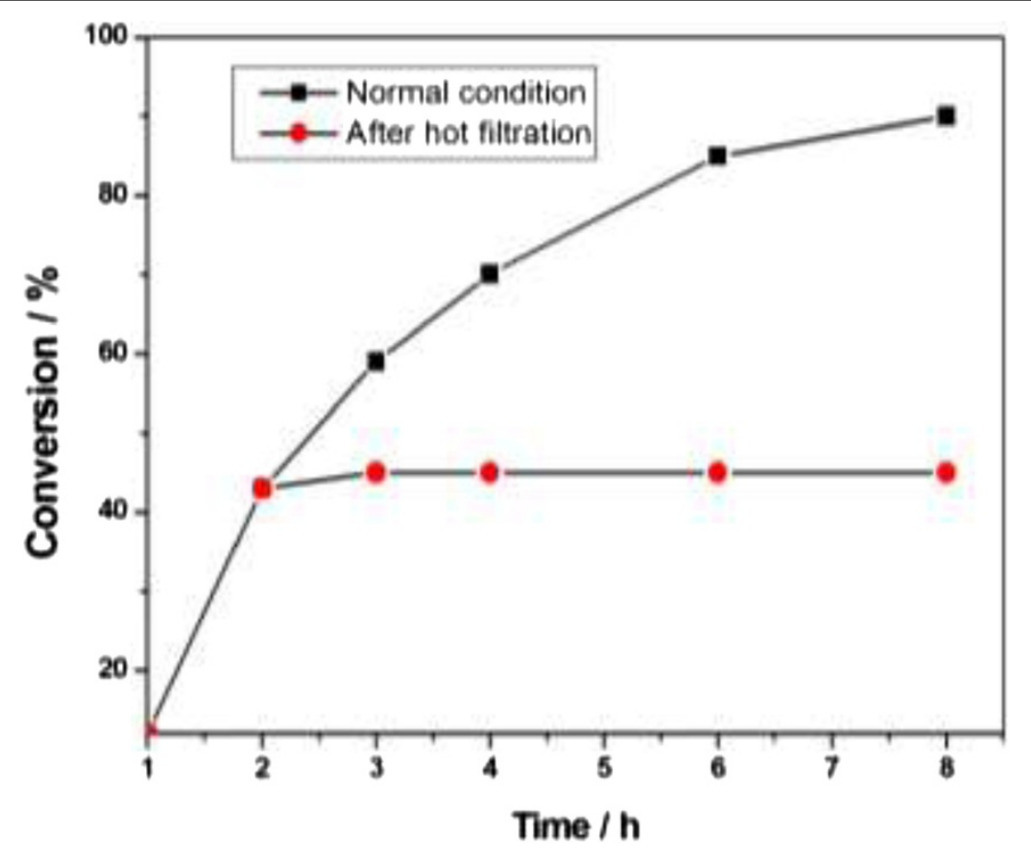

Figure 6 Comparison of normal time profile with that of hot filtration test. Conversions $( \pm 2 \%)$ at different time intervals for each plot were measured by HPLC. 


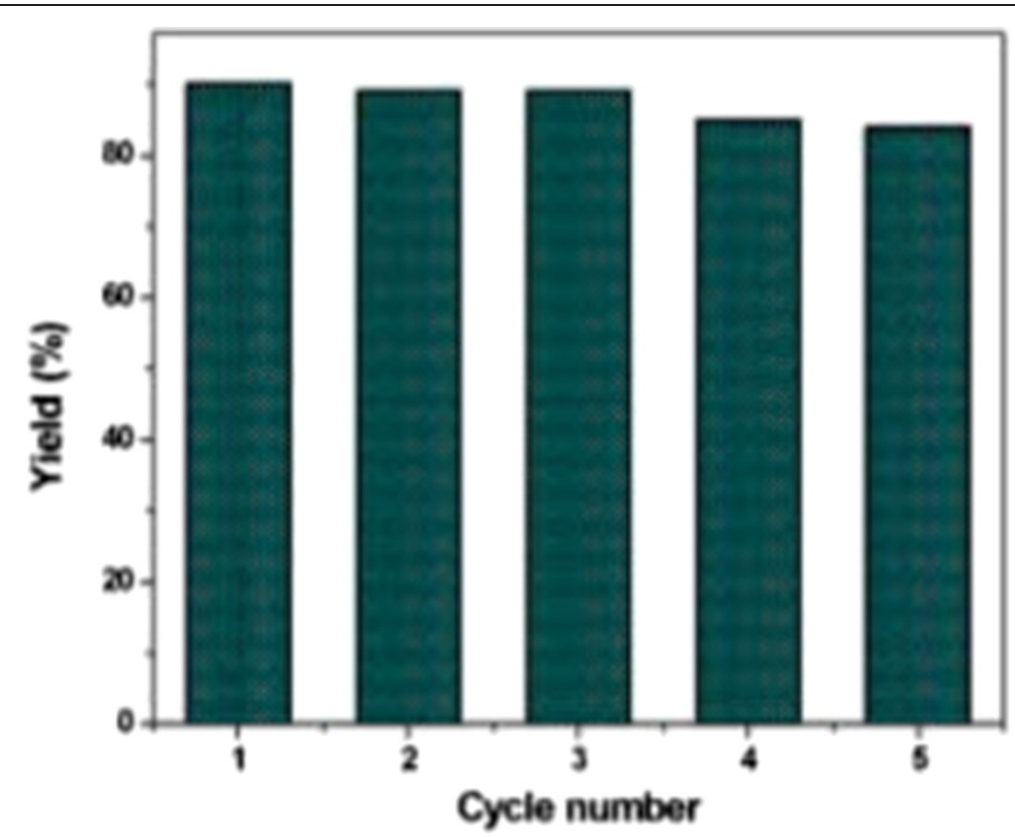

Figure 7 Recycling experiments using CuO@ARF in the C-S cross-coupling reaction between 4-iodoanisole and thiophenol.

bromo-substituents attached with two aromatic rings under Pd-BINAP catalyzed condition was carried out to afford phenothiazine in $84 \%$ isolated yield. The C-N coupling can also be accomplished by using the new catalyst (CuO@ARF) in the presence of L-proline as the ligand (Scheme 1) [46]. The ${ }^{1} \mathrm{H}$ nuclear magnetic resonance (NMR) spectra run in DMSO-D6 and DMSO-D6$\mathrm{D}_{2} \mathrm{O}$ confirmed formation of phenothiazine with the labile $\mathrm{NH}$ proton appeared at $\delta 8.5 \mathrm{ppm}$ (see Additional file 1). We also performed the intramolecular Buchwald coupling in a water medium using both catalytic systems. Although the reaction works well with comparative yield of the phenothiazine in the case of using $\operatorname{Pd}_{2}(\mathrm{dba})_{3}$, the use of $\mathrm{CuO} @ \mathrm{ARF}$ as the catalyst however does not give a satisfactory yield of the desired cyclic product.

A comparison chart of the efficiency of the present catalytic system with other metal-based 'on-water' catalytic systems reported in the literature showing advantages in terms of low loading, high efficiency, stability of the catalyst, recyclability, etc. has been presented in Table 3 .

\section{Conclusions}

Our studies established that poly-ionic resin-supported $\mathrm{CuO}$ NPs (CuO@ARF) are an efficient catalyst in the $\mathrm{C}-\mathrm{S}$ coupling reaction under ligand-free 'on-water' conditions. Low loading of the catalyst, recyclability without leaching, and chemoselectivity amongst aromatic halides are notable features. Further application of the chemoselectivity has been demonstrated in the synthesis of bioactive heterocyclic scaffold phenothiazine. Considering the inexpensive catalytic system along with the application to the synthesis of medicinally important structural scaffold, this heterogeneous catalyst and greener method can find wider applications in organic synthesis.

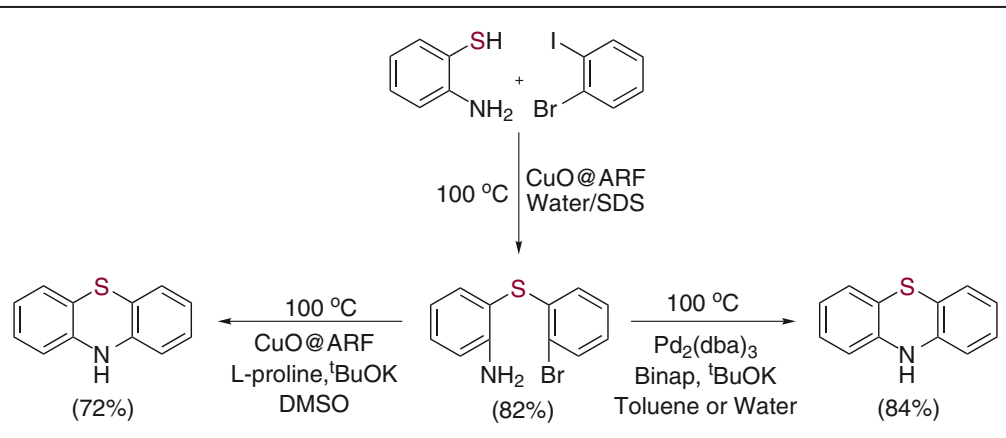

Scheme 1 Synthesis of phenothiazine. 
Table 3 Comparison of various metal-based catalytic 'on-water' C-S coupling reactions with the present system CuO@ARF

\begin{tabular}{|c|c|c|c|c|}
\hline Entry & Catalytic system & Applicability & Remarks & Reference \\
\hline 01 & $\begin{array}{l}\text { Cul }(1 \mathrm{~mol} \%) 1.5 \text { eqv TBAB ( } 1 \text { eqv); } \\
\text { base } \mathrm{KOH}\left(1.5 \text { eqv); } 80^{\circ} \mathrm{C}, 10 \mathrm{~h}\right.\end{array}$ & $\begin{array}{l}\text { With aryl iodide; bromo- and } \\
\text { chloroarenes gave poor yields } \\
\text { even using } 5 \text { mol\% Cul }\end{array}$ & $\begin{array}{l}\text { Excess strong base, not recyclable; Cul is poorly } \\
\text { soluble in water, TBAB is moisture sensitive. }\end{array}$ & {$[27]$} \\
\hline 02 & $\begin{array}{l}\mathrm{CuCl} \text { and } 1,2 \text {-diamine as ligand ( }>2 \text { eqv); } \\
120^{\circ} \mathrm{C} \text { overnight heating }\end{array}$ & $\begin{array}{l}\text { With iodo- and bromoarenes. } \\
\text { No selectivity was examined }\end{array}$ & $\begin{array}{l}\text { Precious 1,2-diamines in }>2 \text {, equivalents, long } \\
\text { reaction time, recyclable using the recovered } \\
\text { solution - catalyst was not separated. }\end{array}$ & {$[28]$} \\
\hline 03 & $\begin{array}{l}\mathrm{Bi}_{2} \mathrm{O}_{3} / \text { Diamine ligand; (each } 10 \text { mol\%); } \\
1 \text { eqv } \mathrm{KOH} \text { at } 100^{\circ} \mathrm{C}\end{array}$ & With aryl iodide & $\begin{array}{l}\text { Presence of a ligand, high loading of the metal } \\
\text { catalyst, long reaction time; recyclable using } \\
\text { the recovered solution - catalyst was not } \\
\text { separated. }\end{array}$ & {$[29]$} \\
\hline 04 & $\begin{array}{l}\mathrm{CoCl}_{2} \cdot 6 \mathrm{H}_{2} \mathrm{O} / \text { cationic } 2,2^{\prime} \text {-bipyridyl system, } \\
1 \text { eqv } \mathrm{KOH} \text {; excess zinc, } 100^{\circ} \mathrm{C}\end{array}$ & $\begin{array}{l}\text { With aryl halides (iodide, bromide, } \\
\text { and chloride). }\end{array}$ & $\begin{array}{l}\text { Presence of cationic } 2,2^{\prime} \text {-bipyridyl; excess } Z \mathrm{n} \text {; } \\
\text { long reaction time; recyclable using the } \\
\text { recovered solution - catalyst was not separated. }\end{array}$ & {$[30]$} \\
\hline 05 & $\begin{array}{l}\mathrm{FeCl}_{3} \cdot 6 \mathrm{H}_{2} \mathrm{O}(10 \mathrm{~mol} \%) \text { - bipyridyl complexes } \\
(10 \mathrm{~mol} \%) ; \mathrm{KOH}(4 \mathrm{eqv}) ; 100^{\circ} \mathrm{C}, 24 \mathrm{~h}\end{array}$ & With aryl iodide & $\begin{array}{l}\text { Excess base, long reaction time; recyclable } \\
\text { using the recovered solution - catalyst was } \\
\text { not separated. }\end{array}$ & {$[31]$} \\
\hline 06 & $\begin{array}{l}\text { CuO@ARF; copper oxide ( } 2.8 \text { mol\%); } \\
\text { base } \mathrm{K}_{2} \mathrm{CO}_{3}\left(1.1 \text { eqv); } 100^{\circ} \mathrm{C}, 8 \mathrm{~h}\right.\end{array}$ & With aryl iodide & $\begin{array}{l}\text { Mild base - nearly equivalent (1: } 1.1 \text { ); shorter } \\
\text { reaction time; chemoselectivity between iodo } \\
\text { and bromo has been utilized in the synthesis } \\
\text { of medicinally important phenothiazine scaffold, } \\
\text { easy separation of heterogeneous catalyst } \\
\text { (by simple filtration of resin beads), recyclable } \\
\text { for five runs without loss of activity; catalytic } \\
\text { amount of SDS, ligand-free. }\end{array}$ & \\
\hline
\end{tabular}

\section{Experimental}

Amberlite IRA 900 (chloride form) was purchased from Acros Organics, Geel, Belgium, and used after washing with water and acetone followed by drying under vacuum. Cupric acetate was purchased from S.D. Fine Chem. Limited, Mumbai, India, and other chemicals were purchased and used directly. For column chromatography, silica (60 to $200 \mu \mathrm{m}$ ) (Sisco Research Laboratories, Mumbai, India), and for TLC, Merck plates coated with silica gel 60, F254 were used (Merck \& Co., Inc., Whitehouse Station, USA). FT-IR spectra were recorded in FT-IR-8300 Shimadzu spectrophotometer (Shimadzu, Kyoto, Japan). NMR spectra were taken in $\mathrm{CDCl}_{3}$ using Bruker Avance AV-300 spectrometer (Bruker AXS, Inc., Yokohama-shi, Japan) operating for ${ }^{1} \mathrm{H}$ at $300 \mathrm{MHz}$ and for ${ }^{13} \mathrm{C}$ at $75 \mathrm{MHz}$. The spectral data were measured using TMS as the internal standard (for ${ }^{1} \mathrm{H}$ ) and $\mathrm{CDCl}_{3}$ (for ${ }^{13} \mathrm{C}$ ). AAS measurements were made using Varian SpectrAA 50B instrument (Varian Medical Systems, Melbourne, Australia). Progress of the reaction was monitored by HPLC (1260 Infinity, Agilent Technologies, Santa Clara, USA), column: ZORBAX RxSIL $(4.6 \times 150 \mathrm{~mm}, 5 \mu \mathrm{m})$, eluent: $\mathrm{n}$-hexane (flow rate $2 \mathrm{~mL} \mathrm{~min}^{-1}$ ). The XRD studies of the powder samples were done using the Rigaku SmartLab (Shibuya-ku, Japan) $(9 \mathrm{~kW})$ diffractometer using $\mathrm{CuK} \alpha$ radiation. HRTEM of the samples was recorded with JEOL JEM-2100 F (FEG) (JEOL Ltd., Akishima-shi, Japan) operating at $200 \mathrm{kV}$.

\section{Preparation of CuO@ARF}

To a solution of $\mathrm{Cu}(\mathrm{OAc})_{2}, \mathrm{H}_{2} \mathrm{O}(50 \mathrm{mg}, 0.25 \mathrm{mmol})$ in DMF $(5 \mathrm{~mL})$ was added ARF (1 g), and the mixture taken in a Teflon-capped sealed tube was heated at $110^{\circ} \mathrm{C}$ for $30 \mathrm{~min}$ with occasional gentle shaking. The supernatant liquid became completely colorless by this time, and the greyish beads of ARF visibly turned brownish. The mixture was cooled to room temperature, and the resin beads were filtered off and washed repeatedly with water $(3 \times 5 \mathrm{~mL})$ and acetone $(2 \times 5 \mathrm{~mL})$. Resulting brown beads were dried under vacuum and used for analyses and evaluation of catalytic activity.

\section{General conditions for C-S cross-coupling reaction}

To a suspension of $\mathrm{CuO@ARF} \mathrm{(200} \mathrm{mg)} \mathrm{in} \mathrm{water}(3 \mathrm{~mL})$ were added aryl halide $(1 \mathrm{mmol})$, thiol $(1.2 \mathrm{mmol})$, $\mathrm{K}_{2} \mathrm{CO}_{3}(1.1 \mathrm{mmol})$, and SDS (10 mol\%), and the reaction mixture was heated in a screw-capped sealed tube at $100^{\circ} \mathrm{C}$ for several hours as mention in Table 2 . Proceeding of the reaction was monitored by TLC at time intervals. After completion, the mixture was cooled, diluted with water $(5 \mathrm{~mL})$, and then filtered through a cotton bed to separate out the resin beads. The resin beads were washed with ethyl acetate $(2 \mathrm{~mL})$, and the filtrate was extracted with ethyl acetate $(3 \times 10 \mathrm{~mL})$. The combined organic layer was dried over anhydrous $\mathrm{Na}_{2} \mathrm{SO}_{4}$ and concentrated under vacuum. The residue obtained was purified by column chromatography using light 
petroleum as the eluent. All products were identified on the basis of spectral data $\left({ }^{1} \mathrm{H}\right.$ and ${ }^{13} \mathrm{C}$ NMR) and also compared with reported melting point (for solid compounds and as available) (see Additional file 1).

The resin beads separated out from the reaction mixture were successively washed with water $(3 \times 5 \mathrm{~mL})$ and acetone $(2 \times 5 \mathrm{~mL})$ and then dried under vacuum for use in the next batch of recycle run.

\section{Preparation of phenothiazine from selective iodo-coupled product (Table 2, entry 17) using Pd-BINAP catalyst}

To a mixture of 2-(2-bromophenylthio)benzeneamine $(1 \mathrm{mmol}, 280 \mathrm{mg})$ in toluene were added ${ }^{\mathrm{t}} \mathrm{BuOK}(1.5 \mathrm{mmol}$, $168 \mathrm{mg}), \mathrm{Pd}_{2}(\mathrm{dba})_{3}(2 \mathrm{~mol} \%)$, and BINAP (4 mol\%). The reaction mixture taken in a screw-capped sealed tube was heated at $100^{\circ} \mathrm{C}$ for $4 \mathrm{~h}$. After cooling, the reaction mixture was diluted with water $(5 \mathrm{~mL})$ and extracted with ethyl acetate $(3 \times 10 \mathrm{~mL})$. The combined extracts were washed with brine, dried $\left(\mathrm{Na}_{2} \mathrm{SO}_{4}\right)$, and evaporated. The residue was purified over a silica gel column to obtain white crystals of phenothiazine (167 mg, 84\%), characterized by ${ }^{1} \mathrm{H}$ and ${ }^{13} \mathrm{C}$ NMR, and compared with literature data (see Additional file 1).

$10 H$-phenothiazine [46], m.p. $185^{\circ} \mathrm{C}$ to $186^{\circ} \mathrm{C}$ (Lit. m.p. $186^{\circ} \mathrm{C}$ to $187^{\circ} \mathrm{C}$ ). ${ }^{1} \mathrm{H}$ NMR (DMSO-d6, $300 \mathrm{MHz}$ ): $\delta /$ ppm 6.72 to $6.77(m, 4 \mathrm{H}, \mathrm{ArH}), 6.89$ to $7.01(m, 4 \mathrm{H}$, $\mathrm{ArH}), 8.58(s, 1 \mathrm{H}, \mathrm{NH}){ }^{13} \mathrm{C}$ NMR (DMSO-d6, $\left.75 \mathrm{MHz}\right)$ : $\delta /$ ppm 114.4, 116.4, 121.8, 126.3, 127.5, and 142.1.

\section{Preparation of phenothiazine from selective iodo-coupled product (Table 2, entry 17) using CuO@ARF catalyst}

To a mixture of 2-(2-bromophenylthio)benzeneamine (1 mmol, $280 \mathrm{mg}$ ) in dimethyl sulfoxide were added tBuOK (1.5 mmol, $168 \mathrm{mg}), \mathrm{CuO@ARF} \mathrm{(200} \mathrm{mg,} 1.8 \mathrm{mg}$ of copper, $2.83 \mathrm{~mol} \% \mathrm{Cu}$ ) and L-proline (5.66 mol\%). The reaction mixture taken in a screw-capped sealed tube was heated at $100^{\circ} \mathrm{C}$ for $48 \mathrm{~h}$. After cooling, the reaction mixture was diluted with water $(5 \mathrm{~mL})$ and extracted with ethyl acetate $(3 \times 10 \mathrm{~mL})$. The combined extracts were washed with brine, dried $\left(\mathrm{Na}_{2} \mathrm{SO}_{4}\right)$, and evaporated. The residue was purified over a silica gel column to obtain white crystals of phenothiazine (143 mg, 72\%), characterized by ${ }^{1} \mathrm{H}$ and ${ }^{13} \mathrm{C}$ NMR and compared with literature data (see Additional file 1).

\section{Additional file}

Additional file 1: Supporting data. ${ }^{1} \mathrm{H}$ and ${ }^{13} \mathrm{C}$ NMR spectral data for sulfanes and scanned spectra and a comparative ${ }^{1} \mathrm{H}-\mathrm{NMR}$ spectra of Phenothiazine.

\section{Competing interests}

The authors declare that they have no competing interests.

\section{Authors' contributions}

DS carried out the whole work and drafted the manuscript. BB conceived the study, followed the development, and finalized the manuscript. Both authors read and approved the final manuscript.

\section{Acknowledgements}

We thank DST, New Delhi, for financial support [Grant No. SR/S1/OC - 86/ $2010(G)]$, and DS thanks CSIR, New Delhi, for awarding research fellowship. We thank Dr. G. De, CSIR-CGCRI, Kolkata for Powder XRD measurements and Prof. A. K. Nandy, I.A.C.S., Kolkata for HRTEM analysis.

Received: 4 September 2014 Accepted: 14 November 2014

Published online: 29 December 2014

\section{References}

1. Procter DJ (2000) The synthesis of thiols, selenols, sulfides, selenides, sulfoxides, selenoxides, sulfones and selenones. J Chem Soc Perkin Trans 1:835-871

2. Liu L, Stelmach JE, Natarajan SR, Chen M-H, Singh SB, Schwartz CD, Fitzgerald CE, O'Keefe SJ, Zaller DM, Schmatz DM, Doherty JB (2003) SAR of 3,4-dihydropyrido[3,2-d]pyrimidone p38 inhibitors. Bioorg Med Chem Lett 13:3979-3982

3. Jones DN (1979) 3. In: Barton DH, Ollis DW (ed) Comprehensive Organic Chemistry, vol 3. Pergamon, New York

4. Kaldor SW, Kalish VJ, Davies JF, II, Shetty BV, Fritz JE, Appelt K, Burgess JA, Campanal KM, Chirgadze NY, Clawson DK, Dressman BA, Hatch SD, Khalil DA, Kosa MB, Lubbehusen PP, Muesing MA, Patick AK, Reich SH, Su KS, Tatlock JH (1997) Viracept (nelfinavir mesylate, AG1343): a potent, orally bioavailable inhibitor of HIV-1 protease. J Med Chem 40:3979-3985

5. De Martino G, Edler MC, La Regina G, Cosuccia A, Barbera MC, Barrow D, Nicholson Rl, Chiosis G, Brancale A, Hamel E, Artico M, Silvestri R (2006) New arylthioindoles: potent inhibitors of tubulin polymerization. 2. Structure-activity relationships and molecular modeling studies. J Med Chem 49:947-954

6. Liu G, Huth JR, Olejniczak ET, Mendoza F, Fesik SW, von Geldern TW (2001) Novel $p$-arylthio cinnamides as antagonists of leukocyte function-associated antigen-1/intracellular adhesion molecule-1 interaction. 2. Mechanism of inhibition and structure-based improvement of pharmaceutical properties. J Med Chem 44:1202-1210

7. Nielsen SF, Nielsen EØ, Olsen GM, Liljefors T, Peters D (2000) Novel potent ligands for the central nicotinic acetylcholine receptor: synthesis, receptor binding, and 3D-QSAR analysis. J Med Chem 43:2217-2226

8. Korth C, May BCH, Cohen FE, Prusiner SB (2001) Acridine and phenothiazine derivatives as pharmacotherapeutics for prion disease. Proc Natl Acad Sci U S A 98:9836-9841

9. Hickman RJS, Christie BJ, Guy RW, White T (1985) Synthesis of aromatic S-substituted derivatives of N-acetyl-L-cysteine. Aust J Chem 38:899-904

10. Khatik GL, Kumar R, Chakraborti AK (2006) Catalyst-free conjugated addition of thiols to a, $\beta$-unsaturated carbonyl compounds in water. Org Lett 8:2433-2436

11. Migita T, Shimizu T, Asami Y, Shiobara J, Kato Y, Kosugi M (1980) The palladium catalyzed nucleophilic substitution of aryl halides by thiolate anions. Bull Chem Soc Jpn 53:1385-1389

12. Eichman CC, Stambuli JP (2011) Transition metal catalyzed synthesis of aryl sulfides. Molecules 16:590-608

13. Guan P, Cao C, Liu Y, Li Y, He P, Chen Q, Liu G, Shi Y (2012) Efficient nickel/ $\mathrm{N}$-heterocyclic carbene catalyzed C-S cross-coupling. Tetrahedron Lett 53:5987-5992

14. Chen C-K, Chen Y-W, Lin C-H, Lin H-P, Lee C-F (2010) Synthesis of CuO on mesoporous silica and its applications for coupling reactions of thiols with aryl iodides. Chem Commun 46:282-284

15. Wong YC, Jayanth $\Pi$, Cheng CH (2006) Cobalt-catalyzed aryl-sulfur bond formation. Org Lett 8:5613-5616

16. Correa A, Carril M, Bolm C (2008) Iron-catalyzed S-arylation of thiols with aryl iodides. Angew Chem Int Ed 47:2880-2883

17. Lai CS, Kao HL, Wang YJ, Lee CF (2012) A general rhodium-catalyzed crosscoupling reaction of thiols with aryl iodides. Tetrahedron Lett 53:4365-4367

18. Liu T-J, Yi C-L, Chan C-C, Lee C-F (2013) Manganese-catalyzed cross-coupling of thiols with aryl iodides. Chem Asian J 8:1029-1034

19. Reddy VP, Kumar AV, Swapna K, Rao KP (2009) Nano indium oxide as a recyclable Catalyst for C-S cross-coupling of thiols with aryl halides under ligand free conditions. Org Lett 11:1697-1700 
20. Hegedus LL, McCabe RW (1984). In: Catalysis Poisoning. Marcel Dekker, New York

21. Chen YJ, Chen HH (2006) 1,1,1-Tris(hydroxymethyl)ethane as a new, efficient, and versatile tripod ligand for copper-catalyzed cross-coupling reactions of aryl iodides with amides, thiols, and phenols. Org Lett 8:5609-5612

22. Bates CG, Gujadhur RK, Venkataraman D (2002) A general method for the formation of aryl-sulfur bonds using copper(I) catalysts. Org Lett 4:2803-2806

23. Heiz U (2007) Landman U Nanocatalysis. Springer-Verlag, Springer Berlin

24. Kamal A, Srinivasulu V, Murty JNSRC, Shankaraiah N, Nagesh N, Reddy TS, Rao AVS (2013) Copper oxide NPs supported on graphene oxide- catalyzed S-arylation: an efficient and ligand-free synthesis of aryl sulfides. Adv Synth Catal 355:2297-2307

25. Schwab RS, Singh D, Alberto EE, Piquini P, Rodrigues OED, Braga AL (2011) C-S cross-coupling of thiols with aryl iodides under ligand-free conditions using nano copper oxide as a recyclable catalyst in ionic liquid. Catal Sci Technol 1:569-573

26. Rout L, Sen TK, Punniyamurthy T (2007) Efficient CuO-nanoparticle-catalyzed C-S cross-coupling of thiols with iodobenzene. Angew Chem Int Ed 46:5583-5586

27. Rout L, Saha P, Jammi S, Punniyamurthy T (2008) Efficient copper(I)-catalyzed C-S cross coupling of thiols with aryl halides in water. Eur J Org Chem 2008:640-643

28. Carril M, SanMartin R, Dominguez E, Tellitu I (2007) Simple and efficient recyclable catalytic system for performing copper-catalysed S-arylation reactions in the presence of water. Chem Eur J 13:5100-5105

29. Malik P, Chakraborty D (2012) Bi(III)-catalyzed C-S cross-coupling reaction Appl Organomet Chem 26:557-561

30. Lan M-T, Wu W-Y, Huang S-H, Luo K-L, Tsai F-Y (2011) Reusable and efficient $\mathrm{CoCl}_{2} 6 \mathrm{H}_{2} \mathrm{O} /$ cationic 2,2'-bipyridyl system-catalyzed S-arylation of aryl halides with thiols in water under air. RSC Adv 1:1751-1755

31. Wu WY, Wang JC, Tsai FY (2009) A reusable $\mathrm{FeCl}_{3} \cdot 6 \mathrm{H}_{2} \mathrm{O}$ /cationic 2,2'-bipyridyl catalytic system for the coupling of aryl iodides with thiols in water under aerobic conditions. Green Chem 11:326-329

32. Basu B, Das S, Das P, Mandal B, Banerjee D, Almqvist F (2009) Palladium supported on a polyionic resin as an efficient, ligand-free, and recyclable catalyst for Heck, Suzuki-Miyaura, and Sonogashira reaction. Synthesis :1137-1146

33. Sengupta D, Saha J, De G, Basu B (2014) Pd/Cu bimetallic NPs embedded in macroporous ion-exchange resins: an excellent heterogeneous catalyst for the Sonogashira reaction. J Mater Chem A 2:3986-3992

34. Paul S, Basu B (2011) Synthesis of libraries of quinoxalines through eco-friendly tandem oxidation-condensation or condensation reactions. Tetrahedron Lett 52:6597-6602

35. Paul S, Basu B (2012) Highly selective synthesis of libraries of 1,2-disubstituted benzimidazoles using silica gel soaked with ferric sulfate. Tetrahedron Lett 53:4130-4133

36. Rhee H-W, Choi SJ, Yoo SH, Jang YO, Park HH, Pinto RM, Cameselle JC, Sandoval FJ, Roje S, Han K, Chung DS, Suh J, Hong J-I (2009) A bifunctional molecule as an artificial flavin mononucleotide cyclase and a chemosensor for selective fluorescent detection of flavins. J Am Chem Soc 131:10107-10112

37. Basu B, Bhuiyan MMH, Das P, Hossain I (2003) Catalytic transfer reduction of conjugated alkenes and an imine using polymer-supported formates. Tetrahedron Lett 44:8931-8934

38. Dar MA, Nam SH, Youn SK, Kim WB (2010) Synthesis, characterization, and electrochemical properties of self-assembled leaf-like $\mathrm{CuO}$ nanostructures. J Solid State Electrochem 14:1719-1726

39. Bahrami K, Khodaei MM, Nejati A (2010) Synthesis of 1,2-disubstituted benzimidazoles, 2-substituted benzimidazoles and 2-substituted benzothiazoles in SDS micelles. Green Chem 12:1237-1241

40. Jammi S, Barua P, Rout L, Saha P, Punniyamurthy T (2008) Efficient ligand-free nickel-catalyzed C-S cross-coupling of thiols with aryl iodides. Tetrahedron Lett 49:1484-1487

41. Cramer CJ, Truhlar DG ACS (eds) (1994) Structure and Reactivity in Aqueous Solution. Washington, DC

42. Sharma G, Kumar R, Chakraborti AK (2008) 'On water' synthesis of 2,4-diaryl2,3-dihydro-1,5-benzothiazepines catalysed by sodium dodecyl sulfate (SDS). Tetrahedron Lett 49:4269-4271

43. Kumar D, Seth K, Kommi DN, Bhagat S, Chakraborti AK (2013) Surfactant micelles as microreactors for the synthesis of quinoxalines in water: scope and limitations of surfactant catalysis. RSC Adv 3:15157-15168
44. Seth K, Roy SR, Pipaliya BV, Chakraborti AK (2013) Synergistic dual activation catalysis by palladium nanoparticles for epoxide ring opening with phenols. Chem Commun 49:5886-5888. and references cited therein

45. Jana S, Dutta B, Bera R, Koner S (2008) Immobilization of palladium in mesoporous silica matrix: preparation, characterization, and its catalytic efficacy in carbon-carbon coupling reactions. Inorg Chem 47:5512-5520

46. Ma D, Geng Q, Zhang H, Jiang Y (2010) Assembly of substituted phenothiazines by a sequentially controlled Cu//-proline-catalyzed cascade C-S and C-N bond formation. Angew Chem Int Ed 49:1291-1294

\section{Submit your manuscript to a SpringerOpen ${ }^{\odot}$ journal and benefit from:}

- Convenient online submission

- Rigorous peer review

- Immediate publication on acceptance

- Open access: articles freely available online

- High visibility within the field

- Retaining the copyright to your article

Submit your next manuscript at $\gg$ springeropen.com 